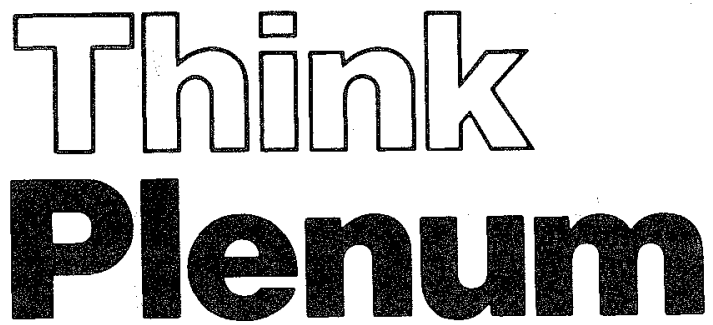

\section{Consciousness and Self-Regulation} Advances in Research and Theory edited by Gary E. Schwartz

Yale University

and David Shapiro

University of California, Los Angeles

"With the biological orientation of this series, the editors have performed a much needed service by providing the reader with a review of the best contemporary research in the field. It is to be recommended to all researchers who maintain an interest in the psychophysiological aspects of consciousness research."

- Michael Malizewski, Psychoenergetic Systems: An International Journal

\section{Volume 2}

This volume explores consciousness as a complex neuropsychological structure system with semantic function; the relationship between sensory, cognitive, and motor processes; factors which regulate our moment-to-moment awareness; the capacity of the brain to process and respond to information that it is not consciously aware of; visceral activity, self-regulation, and EEG alpha rhythms; and a comparison of meditation with different types of biofeedback in the regulation of stress. 470 pp., illus., 1978, $\$ 22.50$

\section{Volume 1}

Volume 1 offers original articles reporting the best research and theories on the nature of conscious experience, the mind-body relationship, cognition and self-report, and other complex problems critical to our understanding of human nature. 422 pp., illus., 1976 , $\$ 22.50$

This series not available from Plenum in the United Kingdom, Europe, the Middle East (including (srael), and Africa.

\section{Advances in Parapsychological Research \\ Volume 1 \\ Psychokinesis \\ edited by Stanley Krippner}

Humanistic Psychology Institute, San Francisco

"[Psychokinesis] can certainly be counted as an addition to the serious literature in parapsychology. The series as envisioned by its editorial board could be a useful reference source for nonspecialists in the field in that it would provide them with periodic summaries of recent advances in parapsychology. It thus would serve as a useful communication device between the parapsychological community and scientists in other specialty areas."

-Douglas M. Stokes, Journal of the American Society for Psychical

Research

248 pp., $1977, \$ 18.95$

\section{Consciousness and the Brain}

A Scientific and Philosophical Inquiry

edited by Gordon G. Globus

University of California, Irvine

\section{Grover Maxwell}

University of Minnesota

and Irwin Savodnik

University of Pittsburgh

"... the occasion of an elite gathering of philosophers and scientists.

There are ten major reports-solid, informed and thoughtful. Some are brilliant, such as Karl Pribram's overall review of the question and his proposal of "constructional realism.'

- Somatics Magazine

378 pp., $1976, \$ 24.50$

Two volumes in the Emotions, Personality, and Psychotherapy Series

\section{The Stream of Consciousness}

Scientific Investigations into the Flow of Human Experience

edited by Kenneth $\mathbf{S}$. Pope

Brentwood Veterans Administration Hospital, Los Angeles

and Jerome L. Singer

Vale University

This new book brings together experts from the fields of human development, medicine, and clinical and experimental psychology. It is the first publication to provide examples, models, and strategies for the creative, scientific examination of consciousness as a continuous flow of experiences. 392 pp., illus., 1978, $\$ 24.50$

Not available from Plenum in the United Kingdom, Europe, the British Commonwealth, and the Middle East (including /srael).

\section{Its companion volume}

\section{The Power of Human Imagination} New Methods in Psychotherapy edited by Jerome L. Singer and Kenneth S. Pope

Examines the major new developments in the clinical application of imagery and related fantasy activities, emphasizing the tremendous adaptive possibilities for treatment of emotional disorders. $426 \mathrm{pp}$., illus., 1978, $\$ 25.00$

\section{Attachment Behavior edited by Thomas Alloway, Patricia Pliner and Lester Krames \\ University of Toronto}

"The book provides a useful overview of some of the current empirical work of both child and comparative psychologists, as well as some of the emerging theoretical considerations in the field. While written for professionals working in the area, little technical background is necessary to read most of the chapters. Thus the book is quite appropriate for an undergraduate library with advanced readers."

- Choice

Advances in the Study of Communication and Affect Series, Volume 3 229 pp., illus., 1977, $\$ 22.50$

Prices slightly higher outside the U.S. 


\title{
ASYMMETRICAL FUNCTION OF THE BRAIN
} MARCEL KINSBOURNE, Editor

Articles by Professor Kinsbourne, one of the leading proponents of research on brain asymmetry, open and close this volume which includes fifteen articles presenting up-to-date information on the functional interactions between the hemispheres of the brain. $\$ 29.95$

\section{A GUIDE FOR BEGINNING PSYCHOTHERAPISTS JOAN S. ZARO, ROLAND BARACH, DEBORAH JO NEDELMAN and IRWIN S. DREIBLATT}

\begin{abstract}
Written with the student in mind, this comprehensive introduction provides practical guidance on the initial tasks and problems confronting the beginning psychotherapist. The authors have avoided the use of "insider's" jargon, making the Guide accessible not only to therapists of all theoretical persuasions, but also to physicians and counselors who may be called upon to respond to a psychological problem. Hardcover $\$ 15.95$ Paper $\$ 6.50$
\end{abstract}

\section{GROUPS AND INDIVIDUALS}

Explanations in Social Psychology

WILLEM DOISE

Douglas Graham, Translator

Professor Doise proposes an approach to the study of intergroup relations that integrates sociological and psychological models of explanation. He discusses the contributions of Lorenz, Freud and Piaget, and offers a detailed account of experimental studies in intergroup relations, including some of the most recent.

Hardcover $\$ 23.95$ Paper $\$ 7.95$

\section{THINKING}

Readings in Cognitive Science

P. N. JOHNSON-LAIRD and P. C. WASON, Editors

This volume contains thirty-four articles on the present state and future prospects of the scientific study of thinking. The editors have brought together a set of readings on topics ranging from cognitive psychology and artificial intelligence, to psycholinguistics and philosophy.

Hardcover $\$ 39.95$ Paper $\$ 10.95$

\section{Cambridge University Press}

32 East 57th Street, New York, New York 10022 